\title{
Economic history of Vietnam
}

Until French colonization in the mid-19th century, Vietnam's economy was uniformly agrarian, subsistence, and village-oriented. French colonizers, however, deliberately developed the regions differently, designating the South for agricultural production and the North for manufacturing. Though the plan exaggerated regional divisions, the development of exports--coal from the North, rice from the South-and the importation of French manufactured goods stimulated internal commerce. ${ }^{[1]}$

When the North and South were divided politically in 1954, they also adopted different economic ideologies: communist in the North and capitalist in the South. Destruction caused by the 1954-75 Second Indochina War seriously strained Vietnam's economy. Across Vietnam, the situation was worsened by the country's 1.5 million military and civilian deaths and its later exodus of 1 million refugees, including tens of thousands of professionals, intellectuals, technicians, and skilled workers. ${ }^{[1]}$

Between 1976 and 1986, the then-unified country had a planned economy. Though the government's Second Five-Year Plan (1976-1981) set extraordinarily high goals for annual growth rates for industry, agriculture, and national income and aimed to integrate the North and the South, the Plan's aims were not achieved: the economy remained dominated by small-scale production, low labor productivity, unemployment, material and technological shortfalls, and insufficient food and consumer goods. ${ }^{[1]}$ The more modest goals of the Third Five-Year Plan (1981-85) were a compromise between ideological and pragmatic factions; they emphasized the development of agriculture and industry. Efforts were also made to decentralize planning and improve the managerial skills of government officials. ${ }^{[1]}$

In 1986 Vietnam launched a political and economic renewal campaign (Doi Moi) that introduced reforms intended to facilitate the transition from a centrally-planned economy to form of market socialism officially termed "Socialist-oriented market economy." Doi Moi combined economic planning with free-market incentives and encouraged the establishment of private businesses in the production of consumer goods and foreign investment, including foreign-owned enterprises. By the late 1990s, the success of the business and agricultural reforms ushered in under Doi Moi was evident. More than 30,000 private businesses had been created, and the economy was growing at an annual rate of more than 7 percent, and poverty was nearly halved. ${ }^{[2]}$

In 2001 the Vietnamese Communist Party (VCP) approved a 10-year economic plan that enhanced the role of the private sector while reaffirming the primacy of the state sector in the economy. In 2003 the private sector accounted for more than one-quarter of all industrial output. However, between 2003 and 2005 Vietnam fell dramatically in the World Economic Forum's Global Competitiveness Report rankings, largely due to negative perceptions of the effectiveness of government institutions. Official corruption is endemic, and Vietnam lags in property rights, the efficient regulation of markets, and labor and financial market reforms. Although Vietnam's economy, which continues to expand at an annual rate in excess of 7 percent, is one of the fastest growing in the world, the economy is growing from an extremely low base, reflecting the crippling effect of the Second Indochina War (1954-75) and repressive economic measures introduced in its aftermath. 


\section{Until 1954}

North, South, and Central Vietnam historically were divided by ethnolinguistic differences, but until the midnineteenth century and the beginning of the French colonial period, they were all agrarian, subsistence, and village-oriented societies.

In pre-colonial Vietnam, agriculture was always the foundation of the country. Wet rice culture began in the Red river delta with the development of dikes. Vietnam became the cradle of forest products, either as a commodity or tribute, for China during her occupation until the tenth century. The dynasties of its independent age from the tenth to nineteenth centuries, due to the Confucian ideology, supported agriculture as the foundation of the society. The farmers, officials and royal relatives were granted lands. The private right of the land was guaranteed by laws. Lands could be transferred, sold or mortgaged. Products from lands would be taxed and gathered in public granaries for the time of famine, war or natural disaster. Trade and markets operated freely under the laws and became the source of tax. Cash or coins circulated were both Chinese and Vietnamese. Banknotes or paper money did exist in the Lê Dynasty (1428-1788). Chinese merchants were the major traders allowed in Vietnam. In the seventeenth century, European merchants came. The Dutch East Indies Company, VOC, became active in trade with the southern kingdom under the Nguyễn lords. Western weapons in exchange of local products were the highlights of economic activity in the seventeenth century.

However Vietnam's economic situation was always under pressure from wars and natural calamities. Famine happened from times to times. Due to the southward expansion, Vietnamese migrants and soldiers were sent to open new lands occupied from the central plain to the Mekong Delta.

In Colonial Vietnam, the French, who needed raw materials and a market for French manufactured goods, altered these commonalities by undertaking a plan to develop the northern and southern regions separately. The South, better suited for agriculture and relatively poor in industrial resources, was designated to be developed agriculturally; the North, naturally wealthy in mineral resources, was selected as the region in which industrial development was to be concentrated. ${ }^{[1]}$

The separation distorted the basic Vietnamese economy by overly stressing regional economic differences. In the North, while irrigated rice remained the principal subsistence crop, the French introduced plantation agriculture with products such as coffee, tea, cotton, and tobacco. The colonial government also developed some extractive industries, such as the mining of coal, iron, and nonferrous metals. A shipbuilding industry was begun in Hanoi; and railroads, roads, power stations, and hydraulics works were constructed. In the South, agricultural development concentrated on rice cultivation, and, nationally, rice and rubber were the main items of export. Domestic and foreign trade were centered around the Saigon-Cholon area. Industry in the South consisted mostly of food-processing plants and factories producing consumer goods. ${ }^{[1]}$

The development of exports—coal from the North, rice from the South-and the importation of French manufactured goods, however, stimulated internal commerce. A pattern of trade developed whereby rice from the South was exchanged for coal and manufactured goods from the North. ${ }^{[1]}$

\section{4-1975}

When the North and South were divided politically in 1954, they also adopted different economic ideologies, one communist and one capitalist. In the North, the communist regime's First Five-Year Plan (1961-65) gave priority to heavy industry, but priority subsequently shifted to agriculture and light industry. ${ }^{[1]}$

During the 1954-75 Second Indochina War, United States air strikes in the North, beginning in early 1965, slowed large-scale construction considerably as laborers were diverted to repairing bomb damage. By the end of 1966, serious strains developed in the North's economy as a result of war conditions. Interruptions in electric power, the destruction of petroleum storage facilities, and labor shortages led to a slowdown in industrial and agricultural activity. The disruption of transportation routes by U.S. bombing further slowed distribution of raw materials and 
consumer goods. In the North, all 6 industrial cities, 28 out of 30 provincial towns, 96 out of 116 district towns, and 4,000 out of 5,788 communes were either severely damaged or destroyed. All power stations, 1,600 hydraulics works, 6 railway lines, all roads, bridges, and sea and inland ports were seriously damaged or destroyed. In addition, 400,000 cattle were killed, and several thousand square kilometres of farmland were damaged. ${ }^{\text {[1] }}$

The economy in the South between 1954 and 1975 became increasingly dependent on foreign aid. The United States, the foremost donor, financed the development of the military and the construction of roads, bridges, airfields and ports; supported the currency; and met the large deficit in the balance of payments. Destruction attributed to the Second Indochina War was considerable. Hanoi claimed that in the South, 9,000 out of 15,000 hamlets were damaged or destroyed, 100,000 square kilometres of farmland and 50,000 square kilometres of forest lands were devastated, and 1.5 million cattle were killed. ${ }^{[1]}$

For Vietnam as a whole, the war resulted in some 1.5 million military and civilian deaths, 362,000 invalids, 1 million widows, and 800,000 orphans. The country sustained a further loss in human capital through the exodus of refugees from Vietnam after the communist victory in the South. According to the United Nations High Commission for Refugees, as of October 1982 approximately 1 million people had fled Vietnam. Among them were tens of thousands of professionals, intellectuals, technicians, and skilled workers. ${ }^{[1]}$

\section{Subsidy phase: 1976-1986}

The Vietnamese economy is shaped primarily by the VCP through the plenary sessions of the Central Committee and national congresses. The party plays a leading role in establishing the foundations and principles of communism, mapping strategies for economic development, setting growth targets, and launching reforms. ${ }^{[1]}$

Planning is a key characteristic of centralized, communist economies, and one plan established for the entire country normally contains detailed economic development guidelines for all its regions. According to Vietnamese economist Vo Nhan Tri, Vietnam's post-reunification economy was in a "period of transition to socialism." The process was described as consisting of three phases. The first phase, from 1976 through 1980, incorporated the Second Five-Year Plan (1976-80)--the First FiveYear Plan (1960-65) applied to North Vietnam only. The second phase, called "socialist industrialization", was divided into two stages: from 1981 through 1990 and from 1991 through 2005. The third phase, covering the years 2006 through 2010, was to be time allotted to "perfect" the transition. ${ }^{[1]}$

The party's goal was to unify the economic system of the entire country under communism. Steps were taken to implement this goal at the long-delayed Fourth National Party Congress, convened in December 1976, when the party adopted the Second Five-Year Plan and defined both its "line of socialist revolution" and its "line of building a socialist economy." The next two congresses, held in March 1982 and December 1986, respectively, reiterated this long-term communist objective and approved the five-year plans designed to guide the development of the Vietnamese economy at each specific stage of the communist revolution. ${ }^{[1]}$

\section{The Second Five-Year Plan (1976-80)}

The optimism and impatience of Vietnam's leaders were evident in the Second Five-Year Plan. The plan set extraordinarily high goals for the average annual growth rates for industry (16 to 18 percent), agriculture ( 8 to 10 percent), and national income (13 to 14 percent). It also gave priority to reconstruction and new construction while attempting to develop agricultural resources, to integrate the North and the South, and to proceed with communization. ${ }^{[1]}$

Twenty years were allowed to construct the material and technical bases of communism. In the South, material construction and systemic transformation were to be combined in order to hasten economic integration with the North. It was considered critical for the VCP to improve and extend its involvement in economic affairs so that it could guide this process. Development plans were to focus equally on agriculture and industry, while initial investment was to favor projects that developed both sectors of the economy. Thus, for example, heavy industry was 
intended to serve agriculture on the premise that a rapid increase in agricultural production would in turn fund further industrial growth. With this strategy, Vietnamese leaders claimed that the country could bypass the capitalist industrialization stage necessary to prepare for communism. ${ }^{[1]}$

Vietnam was incapable, however, of undertaking such an ambitious program on its own and solicited financial support for its Second Five-Year Plan from Western nations, international organizations, and communist allies. Although the amount of economic aid requested is not known, some idea of the assistance level envisioned by Hanoi can be obtained from available financial data. The Vietnamese government budget for 1976 amounted to US\$2.5 billion, while investments amounting to US\$7.5 billion were planned for the period between 1976 and $1980 .{ }^{[1]}$

The economic aid tendered to Hanoi was substantial, but it still fell short of requirements. The Soviet Union, China, and Eastern Europe offered assistance that was probably worth US\$3 billion to US\$4 billion, and countries of the Western economic community pledged roughly US $\$ 1$ billion to US $\$ 1.5$ billion. ${ }^{[1]}$

\section{The Third Five Year Plan (1981-85)}

By 1979 it was clear that the Second Five-Year Plan had failed to reduce the serious problems facing the newly unified economy. Vietnam's economy remained dominated by small-scale production, low labor productivity, unemployment, material and technological shortfalls, and insufficient food and consumer goods. ${ }^{[1]}$

To address these problems, at its Fifth National Party Congress held in March 1982, the VCP approved resolutions on "orientations, tasks and objectives of economic and social development for 1981-85 and the 1980s." The resolutions established economic goals and in effect constituted Vietnam's Third Five-Year Plan (1981-85). Because of the failure of the Second Five-Year Plan, however, the Vietnamese leadership proceeded cautiously, presenting the plan one year at a time. The plan as a whole was neither drawn up in final form nor presented to the National Assembly for adoption. ${ }^{[1]}$

The economic policies set forth in 1982 resulted from a compromise between ideological and pragmatic elements within the party leadership. The question of whether or not to preserve private capitalist activities in the South was addressed, as was the issue of the pace of the South's communist transformation. The policies arrived at called for the temporary retention of private capitalist activities in order to spur economic growth and the completion, more or less, of a communist transformation in the South by the mid-1980s. ${ }^{[1]}$

The plan's highest priority, however, was to develop agriculture by integrating the collective and individual sectors into an overall system emphasizing intensive cultivation and crop specialization and by employing science and technology. Economic policy encouraged the development of the family economy; that is, the peasants' personal use of economic resources, including land, not being used by the cooperative. Through use of an end-product contract system introduced by the plan, peasant households were permitted to sign contracts with the collective to farm land owned by the collective. The households then assumed responsibility for production on the plots. If production fell short of assigned quotas, the households were to be required to make up the deficit the following year. If a surplus was produced, the households were to be allowed to keep it, sell it on the free market, or sell it to the state for a "negotiated price." In 1983 the family economy reportedly supplied 50 to 60 percent of the peasants' total income and 30 to 50 percent of their foodstuffs. ${ }^{[1]}$

Free enterprise was sanctioned, thus bringing to an end the nationalization of small enterprises and reversing former policies that had sought the complete and immediate communization of the South. The new policy especially benefited peasants (including the overwhelming majority of peasants in the South) who had refused to join cooperatives, small producers, small traders, and family businesses. ${ }^{[1]}$

The effort to reduce the capitalist sector in the South nevertheless continued. Late in 1983, a number of import-export firms that had been created in Ho Chi Minh City (formerly Saigon) to spur the development of the export market were integrated into a single enterprise regulated by the state. At the same time, the pace of collectivization in the countryside was accelerated under the plan. By the end of 1985, Hanoi reported that 72 percent of the total number of peasant households in the South were enrolled in some form of cooperative 
organization. $^{[1]}$

Despite the plan's emphasis on agricultural development, the industrial sector received a larger share of state investment during the first two years. In 1982, for example, the approximate proportion was 53 percent for industry compared with 18 percent for agriculture. Limiting state investment in agriculture, however, did not appear to affect total food production, which increased 19.5 percent from 1980 to $1984 .^{[1]}$

The plan also stressed the development of small-scale industry to meet Vietnam's material needs, create goods for export, and lay the foundation for the development of heavy industry. In the South, this entailed transforming some private enterprises into "state-private joint enterprises" and reorganizing some small-scale industries into cooperatives. In other cases, however, individual ownership was maintained. Investment in light industry actually decreased by 48 percent while investment in heavy industry increased by 17 percent during the first two years of the plan. Nonetheless, the increase in light-industry production outpaced that of heavy industry by 33 percent to 28 percent during the same two-year period. ${ }^{[1]}$

The July 1984 Sixth Plenum (Fifth Congress) of the VCP Central Committee recognized that private sector domination of wholesale and retail trade in the South could not be eliminated until the state was capable of assuming responsibility for trade. Proposals therefore were made to decentralize planning procedures and improve the managerial skills of government and party officials. ${ }^{[1]}$

These plans were subsequently advanced at the Central Committee's Eighth Plenum (Fifth Congress) in June 1985. Acting to disperse economic decision making, the plenum resolved to grant production autonomy at the factory and individual farm levels. The plenum also sought to reduce government expenditures by ending state subsidies on food and certain consumer goods for state employees. It further determined that all relevant costs to the national government needed to be accounted for in determining production costs and that the state should cease compensating for losses incurred by state enterprises. To implement these resolutions, monetary organizations were required to shift to modern economic accounting. The government created a new dong in September 1985, and set maximum quotas for the amount permitted to be exchanged in bank notes. The dong also was officially devalued. ${ }^{[1]}$

\section{6-2000}

In 1986 Vietnam launched a political and economic innovation campaign (Doi Moi) that introduced reforms intended to facilitate the transition from a centralized economy to a "socialist-oriented market economy." Doi Moi combined government planning with free-market incentives. The program abolished agricultural collectives, removed price controls on agricultural goods, and enabled farmers to sell their goods in the marketplace. It encouraged the establishment of private businesses and foreign investment, including foreign-owned enterprises. ${ }^{\text {[2] }}$

By the late 1990s, the success of the business and agricultural reforms ushered in under Doi Moi was evident. More than 30,000 private businesses had been created, and the economy was growing at an annual rate of more than 7 percent. From the early 1990s to 2005, poverty declined from about 50 percent to 29 percent of the population. However, progress varied geographically, with most prosperity concentrated in urban areas, particularly in and around Ho Chi Minh City. In general, rural areas also made progress, as rural households living in poverty declined from 66 percent of the total in 1993 to 36 percent in 2002. By contrast, concentrations of poverty remained in certain rural areas, particularly the northwest, north-central coast, and central highlands. ${ }^{[2]}$

Government control of the economy and a nonconvertible currency have protected Vietnam from what could have been a more severe impact resulting from the East Asian financial crisis in 1997. ${ }^{[3]}$ Nonetheless, the crisis, coupled with the loss of momentum as the first round of economic reforms ran its course, has exposed serious structural inefficiencies in Vietnam's economy. Vietnam's economic stance following the East Asian recession has been a cautious one, emphasizing macroeconomic stability rather than growth. While the country has shifted toward a more market-oriented economy, the Vietnamese government still continues to hold a tight rein over major sectors of the economy, such as the banking system, state-owned enterprises, and areas of foreign trade. GDP growth fell to $6 \%$ in 1998 and $5 \%$ in 1999. 


\section{0-present}

The July 13, 2000, signing of the Bilateral Trade Agreement (BTA) between the United States and Vietnam was a significant milestone for Vietnam's economy. The BTA provided for Normal Trade Relations (NTR) status of Vietnamese goods in the U.S. market. Access to the U.S. market will allow Vietnam to hasten its transformation into a manufacturing-based, export-oriented economy. It would also concomitantly attract foreign investment to Vietnam, not only from the U.S., but also from Europe, Asia, and other regions.

In 2001 the Vietnamese Communist Party (VCP) approved a 10-year economic plan that enhanced the role of the private sector while reaffirming the primacy of the state. In 2003 the private sector accounted for more than one-quarter of all industrial output, and the private sector's contribution was expanding more rapidly than the public sector's (18.7 percent versus 12.4 percent growth from 2002 to 2003 ). ${ }^{[2]}$ Growth then rose to $6 \%$ to $7 \%$ in $2000-02$ even against the background of global recession, making it the world's second-fastest growing economy. Simultaneously, investment grew threefold and domestic savings quintupled.

In 2003 the private sector accounted for more than one-quarter of all industrial output. ${ }^{[2]}$ Despite these signs of progress, the World Economic Forum's 2005 Global Competitiveness Report, which reflects the subjective judgments of the business community, ranked Vietnam eighty-first in growth competitiveness in the world (down from sixtieth place in 2003) and eightieth in business competitiveness (down from fiftieth place in 2003), well behind its model China, which ranked forty-ninth and fifty-seventh in these respective categories. Vietnam's sharp deterioration in the rankings from 2003 to 2005 was attributable in part to negative perceptions of the effectiveness of government institutions. Official corruption is endemic despite efforts to curb it. Vietnam also lags behind China in terms of property rights, the efficient regulation of markets, and labor and financial market reforms. State-owned banks that are poorly managed and suffer from non-performing loans still dominate the financial sector. ${ }^{[2]}$

Vietnam had an average growth in GDP of 7.1\% per year from 2000 to 2004. The GDP growth was 8.4\% in 2005, the second largest growth in Asia, trailing only China's. Government figures of GDP growth in 2006, was 8.17\%. According to Vietnam's Minister of Planning and Investment, the government targets a GDP growth of around $8.5 \%$ for 2007 .

On January 11, 2007, Vietnam became WTO's 150th member, after 11 years of preparation, including 8 years of negotiation. Vietnam's access to WTO should provide an important boost to Vietnam's economy and should help to ensure the continuation of liberalizing reforms and create options for trade expansion. However, WTO accession also brings serious challenges, requiring Vietnam's economic sectors to open the door to increased foreign competition. ${ }^{\text {[4] }}$ Although Vietnam's economy, which continues to expand at an annual rate in excess of 7 percent, is one of the fastest growing in the world, the economy is growing from an extremely low base, reflecting the crippling effect of the Second Indochina War (1954-75) and repressive economic measures introduced in its aftermath. Whether rapid economic growth is sustainable is open to debate. The government may not be able to follow through with plans to scale back trade restrictions and reform state-owned enterprises. Reducing trade restrictions and improving transparency are keys to gaining full membership in the World Trade Organization (WTO), as hoped by mid-2006. The government plans to reform the state-owned sector by partially privatizing thousands of state-owned enterprises, including all five state-owned commercial banks. ${ }^{[2]}$

\section{GDP by year}

This chart shows the GDP of Vietnam at market prices (Source: IMF ${ }^{[5]}$ ) 


\begin{tabular}{|l|l|l|}
\hline Year & \multicolumn{1}{|c|}{$\begin{array}{c}\text { GDP } \\
\text { (in millions of New Dong) }\end{array}$} & $\begin{array}{c}\text { Per Capita } \\
\text { Income } \\
\text { (as \% of USA) }\end{array}$ \\
\hline 1980 & 5,713 & 4.19 \\
\hline 1985 & 100,464 & 1.41 \\
\hline 1990 & $41,955,000$ & 0.42 \\
\hline 1995 & $228,892,000$ & 1.04 \\
\hline 2000 & $441,646,000$ & 1.15 \\
\hline 2005 & $806,854,877$ & 1.51 \\
\hline
\end{tabular}

\section{See also}

- Economy of Vietnam

- Economy of the Republic of Vietnam

- History of Vietnam

\section{References}

[1] Vietnam country study (http://lcweb2.loc.gov/frd/cs/vntoc.html). Library of Congress Federal Research Division (December 1987). This article incorporates text from this source, which is in the public domain.

[2] Vietnam country profile (http://lcweb2.loc.gov/frd/cs/profiles/Vietnam.pdf). Library of Congress Federal Research Division (December 2005). This article incorporates text from this source, which is in the public domain.

[3] Vuong, Quan-Hoang Vuong, 2004. "The Vietnam's Transition Economy and Its Fledgling Financial Markets: 1986-2003", Working Papers CEB, No. 04-032.RS, Université Libre de Bruxelles. (http://ideas.repec.org/p/sol/wpaper/04-032.html)

[4] Vuong, Quan-Hoang. Financial Markets in Vietnam's Transition Economy: Facts, Insights, Implications (http://www.amazon.com/ Financial-Markets-Vietnams-Transition-Economy/dp/3639233832/ref=sr_1_1 ie=UTF8\&s=books\&qid=1266916009\&sr=1-1). ISBN 978-3-639-23383-4, VDM Verlag, Feb. 2010, 66123 Saarbrücken, Germany.

[5] http://www.imf.org/external/pubs/ft/weo/2006/01/data/dbcselm.cfm?G=2001 